\title{
PROPRIÉTÉS OPTIQUES ET STRUCTURES CRISTALLINES
}

\author{
J. JERPHAGNON
}

\author{
Centre National d'Etudes des Télécommunications, 92220 Bagneux, France
}

\begin{abstract}
Résumé. - L'aspect le plus simple des relations entre la structure cristalline d'un matériau et ses diverses propriétés optiques (indice de réfraction, biréfringence, activité optique, effets électrooptiques et acousto-optiques...) concerne les règles de sélection imposées par la symétrie du groupe ponctuel sur la forme des tenseurs représentant ces propriétés [1]. Il est par contre beaucoup plus difficile de prévoir, pour un cristal donné, la valeur des différentes susceptibilités optiques.

Le développement des applications optiques implique la recherche et l'élaboration de matériaux ayant, par exemple, des effets électro-optiques ou non linéaires très importants. Dans cette recherche les résultats des théories quantiques ab initio sont difficilement exploitables [2-3]. C'est pourquoi ont été récemment proposés des modèles simplifiés visant, à partir des propriétés physico-chimiques (nature de la liaison) et des considérations de structure, à expliquer et prévoir les propriétés du plus grand nombre possible de matériaux [4-18]. La discussion des travaux effectués dans le cas des composés binaires ou ternaires à structure tétraédrale [4-13] ainsi que de matériaux ferroélectriques de la famille des bronzes oxygénés [15-17] met en lumière les limitations des modèles proposés ainsi que les problèmes soulevés par les méthodes semi-empiriques. On constate en particulier qu'en raison même de leur symétrie trop élevée, certains modèles ne permettent pas d'expliquer les anisotropies optiques. Il est par ailleurs difficile de s'affranchir des délicats problèmes de champ local.

On examine ensuite la possibilité d'étudier quantitativement les relations entre propriétés optiques et structure cristalline de nouvelles classes de matériaux par une méthode comportant trois étapes.
\end{abstract}

1. Décomposer le matériau en unités constitutives. L'unité constitutive est telle que l'on puisse reconstituer le matériau par des opérations géométriques. Elle peut être, suivant les cas, une liaison chimique, un polyèdre d'atomes, une molécule, etc... On la trouve dans plusieurs matériaux.

2. Caractériser l'unité microscopique en décrivant, à l'aide de modèles simplifiés, ses diverses propriétés optiques par un nombre restreint de paramètres (ionicité, polarisabilité...).

3. Déterminer la propriété optique macroscopique par sommation des contributions microscopiques des unités constitutives. L'influence des propriétés de l'unité microscopique n'est pas la même sur les différentes propriétés macroscopiques. Elle dépend fortement de la structure cristalline.

La représentation cartésienne utilisée habituellement pour les tenseurs convient mal pour l'interprétation de grandeurs macroscopiques en fonction de modèles microscopiques. Elle a l'inconvénient de conduire à des calculs assez longs et surtout de masquer au niveau macroscopique les conséquences des hypothèses faites à l'échelle microscopique. On a ainsi été amené à utiliser le formalisme des tenseurs irréductibles [19-20] permettant de définir des quantités invariantes par rapport au groupe des rotations et ayant une interprétation physique simple. On résume brièvement ce formalisme et on met en évidence ses avantages en prenant quelques exemples de l'influence de la structure cristalline sur la biréfringence, l'activité optique [21] et les coefficients électro-optiques de certains matériaux.

Une autre communication du Colloque présente l'analyse des propriétés optiques non linéaires d'une série d'iodates [22] ; elle souligne comment le choix de l'unité microscopique la plus significative dépend des variations entre les structures cristallines des matériaux considérés. Par contre ce choix est souvent plus facile pour les cristaux moléculaires, l'unité constitutive étant, par définition, la molécule elle-même. On propose, dans le cas de la famille des dérivés du benzène, une interprétation des susceptibilités optiques non linéaires en fonction du moment mésomère induit par les différents substituants [23].

Il y a lieu de signaler que la méthode de décomposition en unités microscopiques n'est pas, a priori, limitée à la seule interprétation des propriétés optiques. Elle est susceptible d'être étendue et généralisée à l'étude d'autres propriétés physiques comme la piézo-électricité ou les propriétés magnétiques. En raison même de la simplicité qu'elle prétend avoir au niveau microscopique, elle devrait déboucher sur la mise en évidence de nouvelles relations entre les propriétés physiques des cristaux.

Abstract. - There are several ways to look at the relations between crystallographic structure and optical properties such as index of refraction, birefringence, nonlinearities or photoelasticity. It is easy to deduce the form of the tensors describing optical properties from the point group symmetry of the crystal but it is by far more difficult to predict the value of the optical susceptibilities of a given material. 
General $a b$ initio quantum mechanical calculations are not useful in the search for new efficient materials to be used in optical devices. As a consequence several semi-empirical theories have been lately proposed. They aim at predicting optical properties of large classes of materials by considering the physico-chemical properties (as for instance the chemical bond) in connection with the crystal structure. As shown by the case of tetrahedrally coordinated compounds and of oxygen octahedra ferroelectrics there are several limitations to such theories. Some of them cannot account for the anisotropy of the various optical properties. Most often one has to face delicate questions about the local field corrections.

The possibility of using a three steps method to quantitatively relate optical properties to crystallographic data is discussed. The three steps are

1. Decompose the material into an assembly of microscopic units such as biatomic bonds, tetrahedra, octahedra, etc... The same microscopic unit can be found in several materials.

2. Describe the properties of the microscopic units by using simplified models with only few parameters (ionicity, polarizability...).

3. Express the optical susceptibility tensors as the sum of the contributions of the various microscopic units within the crystal. Note that the contribution at a macroscopic level of the properties of the microscopic units strongly depends on both the crystal structure and the optical property which is considered.

The use of customary cartesian tensor components is not very suitable when changes of the coordinates frames are made. Besides the fact that lengthy calculations are involved, it is almost impossible to follow up to the macroscopical scale all the consequences of the assumptions made at the microscopic level. One therefore has been led to use the irreducible tensors formalism allowing the definition of quantities which are invariant under the three dimensional rotations group. Few specific examples are given to show the usefulness of rotational invariance considerations when studying birefringence, optical activity and electrooptical properties.

Another communication at this Conference deals with optical nonlinearities of iodates and clearly shows the bearing of the variations in the crystallographic structure among related materials on the definition of the suitable microscopic unit. By contrast this definition is generally easier for molecular crystals. Substituted benzenes are considered and a very simple model is proposed for relating the optical nonlinear susceptibilities to the mesomeric moment of the substituents.

The three steps method could be applied to other physical properties such as piezoelectricity or magnetic properties and should lead to new relations amongst physical properties of crystals.

\section{Bibliographie}

[1] Nye, J. F., Physical Properties of Crystals (Oxford Univ. Press, Londres) 1957.

[2] Bloembergen, N., Nonlinear Optics (Benjamin, New York) 1965.

[3] Ducuing, J. et Flytzanis, C., Optical Properties of Solids (F. Abelès, North-Holland, Amsterdam) 1972, p. 859.

[4] Robinson, F. N. H., Bell. Syst. Tech. J. 46 (1967) 913.

[5] Flytzanis, C. et Ducuing, J., Phys. Rev. 178 (1969) 1218.

[6] Jha, S. S. et Bloembergen, N., Phys. Rev. 171 (1968) 891.

[7] Phillips, J. C., Rev. Mod. Phys. 42 (1970) 317.

[8] Van Vechten, J. A., Phys. Rev. 182 (1969) 891.

[9] Levine, B. F., Phys. Rev. Lett. 22 (1969) 789 ; Phys. Rev. 7B (1973) 2500.

[10] Chemla, D. S., Phys. Rev. Lett. 26 (1971) 1441.

[11] Tang, C. L., Flytzanis, C., Phys. Rev. 4B (1971) 2520.

[12] TANG, C. L., IEEE, J. Quantum Electron. 9 (1973) 755.

[13] Chemla, D. S., Begley, R. F., Byer, R. L., IEEE J. Quantum Electron. 10 (1974) 77.

[14] Kurtz, S. K. et Robinson, F. N. H., Appl. Phys. Lett. 10 (1967) 62.
[15] Di Domenico, M. et Wemple, S. H., J. Appl. Phys. 40 (1969) 720.

[16] Wemple, S. H. et Di Domenico, M., Phys. Rev. 4B (1971) 1338 ; Electrooptical and Nonlinear Optical Properties, dans Applied Solid State Science 3 (édité par R. Wolfe, Academic Press, New York) 1972, p. 263.

[17] JeGgo, C. R. et Boyd, G. D., J. Appl. Phys. 41 (1970) 2741.

[18] JeGgo, C. R., Opt. Commun. 1 (1970) 375.

[19] Jerphagnon, J., Phys. Rev. 2B (1970) 1091.

[20] Coope, J. A. R., SNider, R. F. et MCCourt, F. R., J. Chem. Phys. 43 (1965) 2269.

[21] Jerphagnon, J. et Chemla, D. S., Acta Crystallogr. A 28 (1972) 5231 ; à paraître.

[22] Duraffourg, G., Chemla, D. S. et Jerphagnon, J., Revue Phys. Appl. 10 (1975) 363.

[23] Oudar, J. L. et Chemla, D. S., Opt. Commun. 13 (1975) 164. Chemla, D. S., OUdAR, J. L. et Jerphagnon, J., à paraître dans Phys. Rev. 